\title{
The Effect of Plant Extracts Kalanchoe daigremontiana and Aloe arborescens on the Metabolism of Human Multiple Myeloma Cells
}

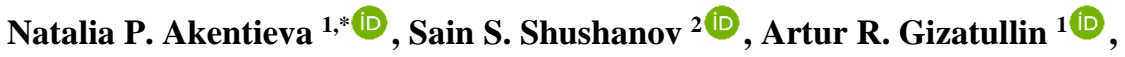 \\ Tat'yana R. Prikhodchenko $^{1}$ (D), Natalia I. Shkondina ${ }^{1}$ (D), Edo D'agaro ${ }^{3}$ (D) \\ 1 Laboratory Biochemical and Cellular Studies, Department Kinetics of Chemical and Biological Processes, Institute of \\ Problems of Chemical Physics Russian Academy of Sciences, Academician Semenov avenue 1, City Chernogolovka, \\ Moscow Region142432, Russia \\ 2 FGBU "National Medical Research Center of Oncology named after N.N. Blokhin" Ministry of Health of Russia, Moscow, \\ st. Kashirskoe highway 24, Russia \\ 3 Udine University, Università Degli Studi di Udine, Via Delle Scienze, 206, 33100 Udine UD, Italy \\ * Correspondence: na_aken@icp.ac.ru;
}

Scopus Author ID 56370037400

Received: 6.01.2021; Revised: 2.02.2021; Accepted: 4.02.2021; Published: 7.02.2021

\begin{abstract}
The effect of plant extracts Kalanchoe daigremontiana, and Aloe arborescens on human multiple myeloma cells' viability was investigated. It was shown that plant extracts of kalanchoe and aloe reduced tumor cells' viability by 13 and $46 \%$, respectively. The combination of plant extracts with doxorubicin showed an additive synergism of action, enhancing the antitumor effect. Treatment of multiple myeloma cells with plant extracts led to a decrease in intracellular reduced glutathione level. The intracellular glutathione level decreased by $25 \%$ under the action of kalanchoe extract and by $63 \%$ under the action of aloe extract. Extracts from kalanchoe and aloe decreased mitochondrial membrane potential by 19 and 53\%, respectively. The results of the study showed that kalanchoe extract increased ATPase activity, but aloe extract did not affect the level of ATPase activity. The results showed that plant extracts of kalanchoe and aloe affect tumor cells' metabolism and contribute to their death. It was concluded that herbal extracts Kalanchoe daigremontiana and Aloe arborescens have antitumor activity, and aloe extract is more effective than kalanchoe.
\end{abstract}

Keywords: herbal extracts, cancer, cytotoxicity

(C) 2021 by the authors. This article is an open-access article distributed under the terms and conditions of the Creative Commons Attribution (CC BY) license (https://creativecommons.org/licenses/by/4.0/).

\section{Introduction}

For many centuries, plants have been a rich source of therapeutic agents. On their basis, well-known and currently widely used drugs have been synthesized, such as the antipyretic agent aspirin, the antitumor drug paclitaxel, the anti-inflammatory drug Novoimanin, and others [1-3]. It is known from the literature that the basis for the synthesis of aspirin was the bark of a willow tree [1], paclitaxel was isolated from the bark of a yew tree (Taxus brevifolia) [2], and novoimanin is obtained from St. John's wort (Hypericum perforatum L.) [3]. Despite synthetic drugs, $75 \%$ of the most important and vital drugs are obtained from plant sources [4]. This indicates that many plant species are still an important source of new drugs for diseases that cannot be treated, such as cancer, HIV, and others. Medicinal plants include Kalanchoe daigremontiana and Aloe arborescens. 
Kalanchoe daigremontiana is a herbaceous succulent plant, a species of the Kalanchoe genus of the Crassulaceae family. According to the information of traditional medicine, the juice of this plant has long been used in everyday life for the treatment of many diseases since it has hemostatic, wound healing, and anti-inflammatory properties [5]. Extracts from this plant's leaves are commonly used to treat diseases such as bacterial, fungal, and viral infections, asthma, and ulcers. It is known from the literature that the leaves of this plant have antimicrobial [6], antifungal [7], anti-inflammatory, analgesic [8,9], antihypertensive [10], anti-diabetic effects [11]. Many active compounds have been identified in the kalanchoe, including flavonoids, glycosides, steroids, and organic acids [12-14], which have various antibacterial properties antitumor, prophylactic anti-cancer, and insecticidal. Despite the wide range of therapeutic potential, the antitumor activity of $K$. daigremontiana is not well understood. Aloe arborescens is an evergreen succulent plant, a species of the genus Aloe of the Asphodeloideae family. The plant's leaves and sap contain enzymes, vitamins, phytoncides, aloin, nataloin, rabarberon, homonatalain, emodin, resinous substances, and traces of essential oils [15]. It is known that aloe preparations have a laxative, choleretic effect, have pronounced anti-inflammatory and anti-burn properties [16]. Aloe juice has a bacteriostatic effect against many groups of microbes: staphylococcus, streptococcus, diphtheria, typhoid, and dysentery sticks. At present, it is known that aloe extract inhibits the growth of tumor cells in the intestine, colon, and breast [17-19]. It has been shown that aloe-emodin, a natural anthraquinone compound, inhibits tumor development in a mouse's colon [20,21]. However, the cytotoxic activity of aloe on multiple myeloma cells has not been studied.

Multiple myeloma (MM) accounts for about $1 \%$ of all malignant neoplasms and slightly more than $10 \%$ of hematological malignancies; therefore, the search for new methods of its treatment is very urgent. The manifestation of side effects when using chemicals, surgical methods, and the need for a long (sometimes years) correction of the pathological process makes doctors pay attention to traditional medicine possibilities. Medicinal plants can be effective in preventing the recurrence of cancer. In many cases, only herbal medicine allows to avoid complications caused by the use of chemotherapy. Herbal remedies can remove toxic substances and metabolic products due to the diuretic effect, increase the liver's antitoxic function, and stabilize cell membranes. Therefore, the search for plant extracts with antitumor activity is important for cancer medicine.

The study aimed to evaluate the antitumor activity of Kalanchoe daigremontiana and Aloe arborescens extracts on MM cells (line RPMI 8226). This work aimed to study the mechanism action of plant extracts of kalanchoe and aloe on MM cells' metabolism.

\section{Materials and Methods}

\subsection{Materials.}

We used the growth medium RPMI (low glucose-1 g/L, L-glutamine, $25 \mathrm{mM}$ HEPES, sodium pyruvate, Biowest, France), bovine serum (FBS, Biowest, France), gentamicin (10 $\mathrm{mg} / \mathrm{ml}$, Biowest, France). Plastic dishes (culture flasks $25 \mathrm{~cm}^{2}$, disposable pipettes) for growing the cell culture were purchased from Corning-Costar, (USA).

\subsection{Isolation of plant extracts.}

For research, we used plant extracts obtained from Kalanchoe daigremontiana (Kalanchoe daigremontiana, Raym.-Hamet \& H. Perrier, 1914) and Aloe arborescens (Aloe 
arborescens Mill., 1768). The plants were grown in soil at a temperature of 22-240 (day/night), illumination of $2 \mathrm{klk}$, and a photoperiod of 10 hours. The leaves of aloe and kalanchoe were washed, dried, crushed with scissors, and then ground in a mortar until smooth. The resulting mass was poured with distilled water in a ratio of 1: 3 for aloe and 1: 0.5 for kalanchoe and filtered through 4 layers of gauze. The resulting juice was used further in experiments immediately after production.

\subsection{Analysis of the optical spectra of plant extracts.}

The spectra of plant extracts were recorded on a Varian Cary Eclipse spectrofluorimeter (Agilent Technologies, USA).

\subsection{Analysis of plant extracts by NMR spectroscopy.}

For NMR spectroscopy aloe and kalanchoe leaves were crushed with scissors, then ground in a mortar until smooth. The resulting mass was added $2 \mathrm{ml}$ of deuterated water $\left(\mathrm{D}_{2} \mathrm{O}\right)$ and filtered through 4 layers of gauze. The prepared samples were analyzed using NMR. ${ }^{1} \mathrm{H}$ NMR spectra were recorded on a high-resolution Bruker AVANCE III $500 \mathrm{MHz}$ spectrometer (USA) at room temperature $\left(23 \pm 1^{0}\right)$ with an operating frequency of $500 \mathrm{MHz}$. Samples for study were placed in standard high-resolution ampoules with an outer diameter of $5 \mathrm{~mm}$. The ${ }^{1} \mathrm{H}$ spectra were recorded using a standard pulse program, including a $90^{0}$ pulses sequence with a delay of $12 \mathrm{~s}$ between them and 32 to 256 accumulations. The chemical shift scale was calibrated using the residual protons of the solvent signal (DMSO-d6, $\delta \mathrm{H}=2.5 \mathrm{ppm}$ ). Analysis of ${ }^{1} \mathrm{H}$ NMR spectra was performed using the ACD/C + H NMR Predictors Program.

\subsection{Organic elemental analysis of plant extracts.}

Organic elemental analysis of plant extracts was carried out by atomic adsorption on an Elementar Vario EL CubE device (Germany). Lyophilized weighed portions of plant extracts were burned in a stream of oxygen at 1150 , while $\mathrm{N}$ was oxidized to $\mathrm{N}_{2}, \mathrm{C}$ to $\mathrm{CO}_{2}, \mathrm{H}$ to $\mathrm{H}_{2} \mathrm{O}$, and $\mathrm{S}$ to $\mathrm{SO}_{2}$. The content of $\mathrm{N}, \mathrm{C}, \mathrm{H}$, and $\mathrm{S}$ was obtained as a percentage.

\subsection{Cell lines.}

We used human multiple myeloma cells (MM, cell line RPMI 8226, kindly provided by S.S. Shushanov, FGBU "National Medical Research Center of Oncology named after N.N. Blokhin", Ministry of Health of Russia, Moscow). The origin of the indicated cell line: human, bone marrow, myeloma.

\subsection{Culture cells.}

Cells cultured in growth medium RPMI with $10 \% \mathrm{FBS}$ at $37^{\circ}, 5 \% \mathrm{CO}_{2}$ and $95 \%$ humidity. The cells were grown to $90 \%$ density in culture flasks.

\subsection{Determination of the cytotoxicity of plant extracts.}

The cytotoxicity of plant extracts of kalanchoe and aloe was determined by staining cells with aniline dye trypan blue [22]. For the analysis, plant extracts were used (the initial protein concentration for aloe is $16.6 \mathrm{mg} / \mathrm{ml}$, for kalanchoe- $44.8 \mathrm{mg} / \mathrm{ml}$ ). To assess the cytotoxicity, plant extracts of kalanchoe and aloe $(2 \mathrm{ml}$, final protein concentration $1.57 \mathrm{mg} / \mathrm{ml})$ 
were added to MM cells (2 016000 cells $/ 28 \mathrm{ml}$ ), and an equal amount of growth medium was added to control vials and incubated for 24 hours at $37^{0}, 5 \% \mathrm{CO}_{2}$. Then $0.2 \mathrm{ml}$ of cell suspension was taken from each vial, trypan blue solution $(0.1 \mathrm{ml} 0.5 \%$ in $0.9 \% \mathrm{NaCl}$ solution $)$ was added, incubated with a dye for $10 \mathrm{~min}$ at $37^{\circ}$, and the number of live, dead cells and the total number of cells were counted in the Goryaev chamber. The cytotoxic index (CTI) was calculated using the formula: (number of dead cells / total number of cells) x $100 \%$.

\subsection{Analysis of the effect of plant extracts on cell viability.}

Plant extracts' effect on NADH dehydrogenases' activity in MM cells was assessed using the AlamarBlue ${ }^{\circledR}$ Cell Viability Assay fluorescence method (ThermoFisher Scientific, USA). This method is based on mitochondrial NADH dehydrogenases' ability to oxidize $\mathrm{NADH}$ and reduce the dye resazurin to fluorescent resofurin in living cells [23]. Equal amounts of plant extracts $(10 \mu \mathrm{l}$, final protein concentration $0.17 \mathrm{mg} /$ well) were added to MM cells (3 200 cells per well), and an equal amount of phosphate-buffered saline (PBS, $100 \mathrm{mM}, \mathrm{pH}=7$, 2) was added to control wells. Also, to compare the effect of plant extracts with doxorubicin (a known anti-cancer drug), doxorubicin (final concentration $1.98 \mu \mathrm{M}$ ) was added to MM cells. To investigate plant extracts' combined effect with this drug, doxorubicin was used in combination with plant extracts. The samples were incubated for $20 \mathrm{~min}$ at $37^{\circ}$. Then AlamarBlue ${ }^{\circledR}$ reagent $(10 \mu \mathrm{l})$ was added, and the fluorescence intensity was measured after 24 hours at $\mathrm{E}_{\mathrm{ex}} / \mathrm{E}_{\mathrm{em}}=570 / 590 \mathrm{~nm}$ on a Spark $10 \mathrm{M}$ spectrofluorometer (USA).

\subsection{Analysis of the effect of plant extracts on glutathione level.}

The effect of plant extracts on the level of reduced glutathione in MM cells was assessed using o-phthalic aldehyde according to the procedure [24]. This method is based on the fact that the amino and sulfhydryl groups of glutathione react with an o-phthalic aldehyde, reducing it, forming a cyclic, intensely fluorescent product. Human MM cells were seeded in a 96-well plate (45000 cells/well), and cells were grown for 24 hours in an incubator at $37^{\circ}, 5 \% \mathrm{CO}_{2}$, and $95 \%$ humidity. Then, plant extracts were added to the wells $(20 \mu 1$, final protein concentration $0.34 \mathrm{mg} / \mathrm{well}$ ), and an equal amount of PBS was added to the control and incubated for $15 \mathrm{~min}$. The cells were then washed twice with PBS, and a solution of cold distilled water $(400 \mu \mathrm{l})$ containing $17.5 \% \mathrm{HPO}_{3}$ was added. After incubation for $10 \mathrm{~min}$, the solution was removed, and PBS $(250 \mu \mathrm{l}, 100 \mathrm{mM}, 5 \mathrm{mM}$ EDTA, $\mathrm{pH}=8.0)$ and $100 \mu \mathrm{o}$ phthalic aldehyde $(0.1 \%$ in ethanol) were added to the cells, incubated for $15 \mathrm{~min}$ at room temperature. Then, glutathione's fluorescent adduct was determined at $\mathrm{E}_{\mathrm{ex}} / \mathrm{E}_{\mathrm{em}}=350 / 420 \mathrm{~nm}$ on a Spark 10M spectrofluorimeter (USA).

\subsection{Analysis of the effect of plant extracts on the level of membrane potential.}

The effect of plant extracts on the level of membrane potential in MM cells was determined by the fluorimetric method using the JC-1 dye (Invitrogen, USA). This method is based on the fact that JC-1 accumulates in mitochondria in proportion to the change in membrane potential $(\Delta \Psi \mathrm{m})$, forming aggregates that fluoresce in the red range [25]. In the cytoplasm, JC-1 exists as a monomer that fluoresces in the green range. The ratio of red to green fluorescence (Fred/Fgreen) is proportional to the membrane potential change $(\Delta \Psi \mathrm{m})$. Plant extracts ( $20 \mu \mathrm{l}$, final protein concentration $0.34 \mathrm{mg} /$ well) were added to MM cells (43800 cells per well). An equal amount of PBS was added to the control and incubated for $15 \mathrm{~min}$. 
Doxorubicin (final concentration $4.52 \mu \mathrm{M}$ ) was used for comparison. Then, JC-1 (27 $\mu \mathrm{M}$ ) was added in the dark and incubated for $30 \mathrm{~min}$ at $37^{\circ}$. Red fluorescence was measured at Eex/Eem $=570 / 595 \mathrm{~nm}$, green fluorescence was determined at $E_{e x} / E_{\mathrm{em}}=485 / 535 \mathrm{~nm}$ on a Spark $10 \mathrm{M}$ spectrofluorometer (USA).

\subsection{Determination of protein in plant extracts.}

The protein content in the samples was determined by the Bradford method, using bovine serum albumin as a standard [26].

\subsection{Analysis of the effect of plant extracts on ATPase activity.}

ATPase activity was measured in cell lysates by the colorimetric method using the ATPase activity analysis kit (BioVision Kit, USA) by the standard manual. Briefly, MM cells were seeded and grown in culture flasks to a density of $10^{6}$. Then whole MM cells $\left(2 \times 10^{6}\right)$ were quickly homogenized with a buffer $(400 \mu \mathrm{l})$ cooled on ice, and the samples were placed on ice for $10 \mathrm{~min}$. The samples were then centrifuged at $10000 \mathrm{~g}$ at $4^{0}$ for $10 \mathrm{~min}$, and the supernatant was collected. Endogenous phosphate was removed by using the ammonium sulfate method. The lysates of MM cells $(5 \mu 1$, protein concentration $123.4 \mathrm{mg} / \mathrm{ml})$ were applied in four replicates to a clear 96-well plate (labeled "background control", and "sample ATPase activity"). Then the samples of plant extracts (for aloe $5 \mu$, protein concentration $13.12 \mathrm{mg} / \mathrm{ml}$, and for kalanchoe $5 \mu \mathrm{l}$, protein concentration $28.89 \mathrm{mg} / \mathrm{ml}$ ) were added to the test lysates and incubated for 15 min on ice. For reagent control, an ATPase assay buffer (100 $\mu 1)$ was added. ATPase positive control $(10 \mu \mathrm{l})$ diluted into of ATPase assay buffer $(190 \mu \mathrm{l})$. The ATPase positive control $(20 \mu \mathrm{l})$ was added into wells and adjusted the final volume to $100 \mu \mathrm{l}$ with ATPase assay buffer. For each well, $100 \mu \mathrm{l}$ of a reaction mixture containing ATPase assay buffer $(98 \mu \mathrm{l})$ and ATPase substrate $(2 \mu \mathrm{l})$ was prepared. Then $100 \mu \mathrm{l}$ of the reaction mixture was added to each well for positive control, reagent control, and test samples and incubated at $25^{0}$ for $30 \mathrm{~min}$.

The measurement was carried out as follows: added $10 \mu 1$ ATPase assay developer for assay to all standards, ATPase positive control, and test samples and background control samples, incubated at $25^{0}$ for $30 \mathrm{~min}$ and measured absorbance (OD) at $650 \mathrm{~nm}$ at the end of incubation time.

The calculation of ATPase activity was carried out as follows: plotted the phosphate standard curve. The sample background is corrected by subtracting a higher value obtained from background control or reagent control from all sample readings. The ATPase activity of the tested samples was calculated: $\Delta \mathrm{OD}=\mathrm{A}_{2}-\mathrm{A}_{1}$. We used $\Delta \mathrm{OD}$ to the standard phosphate curve to obtain $\mathrm{B}$ nmol of phosphate generated by ATPase during the reaction time (e.g., $t=$ $30 \mathrm{~min})$. The formula was used to calculate the activity of an ATPase sample $=\mathrm{B} /(\mathrm{t} \times \mathrm{V}) \times \mathrm{D}$ $=\mathrm{nmol} / \mathrm{min} / \mu \mathrm{l}=\mathrm{mU} / \mu \mathrm{l}=\mathrm{U} / \mathrm{ml}$. Where: $\mathrm{B}$ is the amount of phosphate from the standard curve $(\mathrm{nmol}), \mathrm{t}$ is the reaction time $(\mathrm{min}), \mathrm{V}$ is the volume of the sample added to the reaction well $(\mu \mathrm{l}), \mathrm{D}$ is the dilution factor of the sample. Unit definition: one ATPase unit is the amount of enzyme that generates $1.0 \mu \mathrm{mol}$ phosphate per min at $\mathrm{pH} 7.5$ at $25^{\circ}$. Data are presented as the average of three repeated experiments. 


\subsection{Analysis of the effect of plant extracts on total amount ATP.}

The total amount of ATP was measured in cell lysates by a fluorometric method using the ab83355 ATP assay kit (Abcam, USA) following the manual. The analysis is based on glycerol phosphorylation to obtain a product that can be easily quantified fluorometrically $\left(\mathrm{E}_{\mathrm{ex}} / \mathrm{E}_{\mathrm{em}}=535 / 587 \mathrm{~nm}\right)$ [27]. Briefly, multiple myeloma cells were seeded and grown in culture flasks to a density of $10^{6}$ cells and treated with plant extracts or untreated (positive control). Plant extracts ( $2 \mathrm{ml}$, protein concentration $16.64 \mathrm{mg} / \mathrm{ml}$ ) were added to the experimental flask, and an equal amount of growth medium was added to the control flask and incubated for 15 $\min$ at $37^{0}$ in $5 \% \mathrm{CO}_{2}$. Then, cell lysates were prepared according to the protocol. The cell suspension with plant extracts was transferred to centrifuge tubes. After that, the cells were centrifuged for 5 minutes at $3000 \mathrm{rpm}$, the supernatant was removed, and the cells $\left(1 \times 10^{6}\right)$ were washed with cold PBS $(0.1 \mathrm{M}, \mathrm{pH}=7.2)$ and re-suspended in $200 \mu \mathrm{l}$ of ATP assay buffer. Then the cells were destroyed by pipetting up and down a few times. Next, cells were centrifuged for 5 minutes at $4^{0}$ and $13000 \mathrm{~g}$ in a cold microfuge to remove any insoluble material. The supernatants were collected and transferred to new tubes, which were kept on ice. Cell samples may contain enzymes that can interfere with the assay. To remove these enzymes from samples, deproteinizing sample preparation kit - TCA (ab204708, USA) has been used.

Then the samples $(10 \mu \mathrm{l})$ were added to a 96-well plate (labeled "background control" and "ATP samples"), and the final volume was adjusted to $50 \mu 1$ with ATP assay buffer. For each well, $50 \mu \mathrm{l}$ of a reaction mixture containing ATP assay buffer $(45.8 \mu \mathrm{l})+$ ATP probe $(0.2$ $\mu 1)$, ATP converter $(2 \mu \mathrm{l})$, developer mix $(2 \mu \mathrm{l})$ was prepared and added to each well. The background reaction mixture was the same, but without the ATP converter (in the absence of an ATP converter, the analysis detects only glycerol phosphate, but not ATP). Then we added $50 \mu \mathrm{l}$ of background reaction mix into the background control sample wells. Samples were mixed and incubated at room temperature for $30 \mathrm{~min}$ in the dark. Then immediately measured output on a microplate reader at $\mathrm{E}_{\mathrm{ex}} / \mathrm{E}_{\mathrm{em}}=535 / 587 \mathrm{~nm}$.

The total amount ATP calculation was carried out as follows: subtracted the sample background control from sample readings. The adjusted values for each standard are plotted against the final ATP concentration.

The standard curve was used for adjusted relative fluorescence of the sample to obtain the amount of ATP (B) in the sample wells. Concentration of ATP ( $\mathrm{nmol} / \mu \mathrm{l}$ or $\mu \mathrm{mol} / \mathrm{ml}$ or $\mathrm{mM})$ in the test samples was calculated as: ATP concentration $=(\mathrm{V} / \mathrm{B} \times \mathrm{D}) \times \mathrm{DDF}$. Where: B $=$ amount of ATP in the sample well calculated from a standard curve (nmol or mM); V = sample volume added in the sample wells $(\mu 1) ; \mathrm{D}=$ sample dilution factor if the sample is diluted to fit within the standard curve range (before reaction well set up); DDF = deproteinization dilution factor. Data are presented as the average of three repeated experiments.

\subsection{Statistical analysis.}

All data are presented as the average of three replicate experiments. Statistical analysis of the data was carried out using the GraphPad Prizm software, One-Way ANOVA. Differences were considered significant at $(*-p \leq 0.05)$. An asterisk indicates statistically significant differences between the positive control and all other types of treatments. 


\section{Results and Discussion}

\subsection{Results.}

First, to characterize the biologically active substances that make up the plant extracts, optical and NMR spectra of kalanchoe and aloe were recorded. As shown in Figure 1(a), the kalanchoe leaf extract's optical absorption spectrum has a maximum at $425 \mathrm{~nm}$, small peaks at 350 and $500 \mathrm{~nm}$, and a shoulder at $600 \mathrm{~nm}$. The optical spectrum of aloe showed a maximum at $475 \mathrm{~nm}, 2$ small peaks at 330, $350 \mathrm{~nm}$, and a shoulder at $425 \mathrm{~nm}$ (Figure 1b).

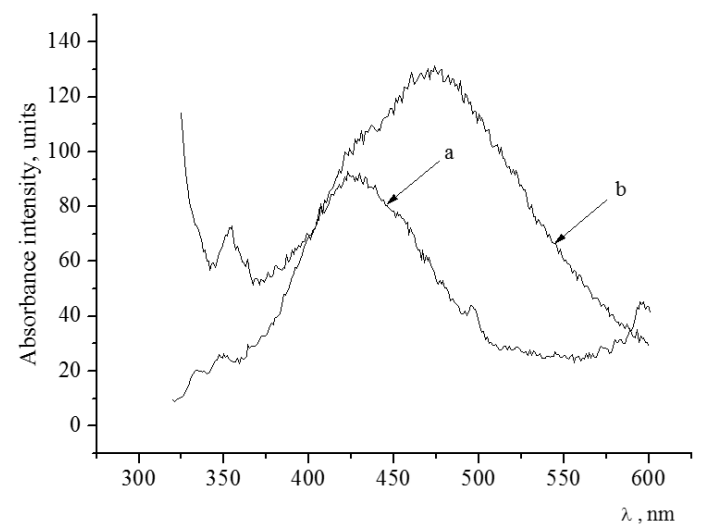

Figure 1. Optical absorption spectrum of plant extracts Kalanchoe daigremontiana (a) and Aloe arborescens (b).

The NMR spectrum of kalanchoe is shown in Figure 2 (a).

A
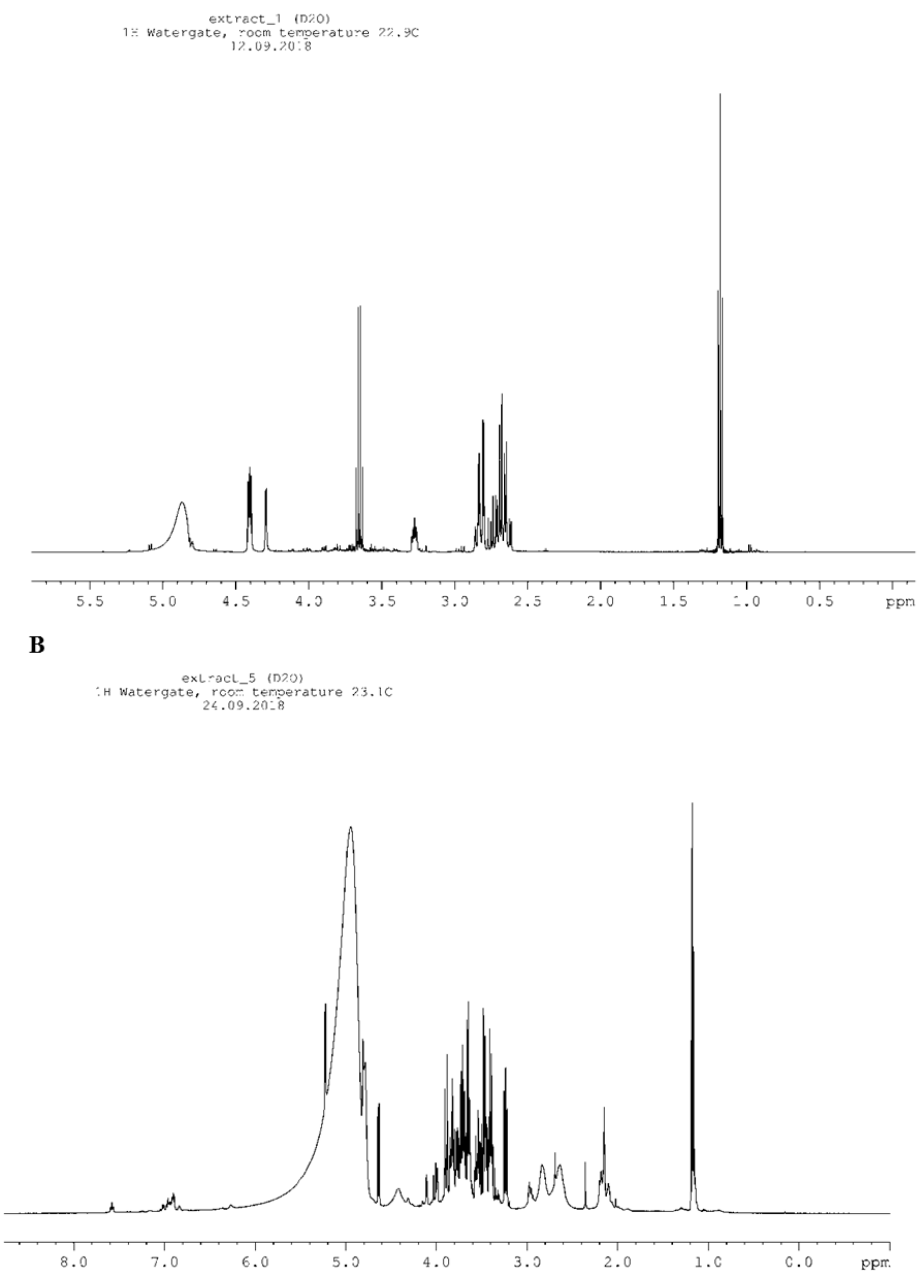

Figure 2. ${ }^{1} \mathrm{H}$ NMR spectrum of plant extracts (a) Kalanchoe daigremontiana; (b) Aloe arborescens. 
As shown in Figure 2, the ${ }^{1} \mathrm{H}$ NMR spectrum contains many functional groups present in the composition of chemical compounds. Specifically, the NMR spectrum from kalanchoe extract showed the presence of chemical shifts specific to functional groups such as $\delta 5.13$ (methylene group), 4.4 (methine proton), 4.21 (secondary hydroxyl), 1.42 (orthoacetate), 3.65 (ether), 3.3 (aldehyde group), 2.5 (ketone group), 2.75 (OH- hydroxyl proton). The results of the analysis of the spectra indicate the presence in the composition of Kalanchoe daigremontiana of various biologically active substances, such as flavonoids, glycosides, steroids, terpenodes, bufadienolides, bryophyllins -A, -B, -C, and organic acids, which were previously identified in other species of Kalanchoe pinnata, Kalanchoe gracilis, Bryophyllum calycinum [27-29].

NMR spectrum from aloe extract demonstrated the presence of chemical shifts specific for functional groups such as $\delta 5.0$ (methylene group), 4.8 (halogens), 1.1 (carbonyl group), 3.3 (aldehyde group), 3.5 (methylene groups), 3.6 (ether), 2.5 (ketone group), 2.75 (hydroxyl proton $\mathrm{OH}^{-}$), 2.1 (acetyl group) (Figure $2 \mathrm{~b}$ ). The spectra analysis indicated the presence of the aloenin and aloe-emodin in the composition of aloe, as was shown earlier for Aloe vera [1720].

For a complete characterization of the extracts, we performed an organic elemental analysis. Using this analysis, we determined the quantitative content of elements in plant extracts (Table 1).

Table 1. Organic elemental analysis of Kalanchoe daigremontiana and Aloe arborescens extracts. Values are given as mean \pm S.D. of two independent experiments.

\begin{tabular}{|c|c|c|c|c|}
\hline Sample & Content of C, \% & Content of $\mathrm{H}, \%$ & Content of $\mathrm{N}, \%$ & Content of S, \% \\
\hline $\begin{array}{l}\text { Extract of } \\
\text { Kalanchoe }\end{array}$ & $31.53 ; 31.56$ & $4.420 ; 4.438$ & $0.90 ; 0.91$ & $0.354 ; 0.296$ \\
\hline Mean value & 31.54 & 4.429 & 0.91 & 0.325 \\
\hline Standard deviation & 0.02 & 0.013 & 0.01 & 0.041 \\
\hline Extract of Aloe & $38.21 ; 38.14$ & $5.253 ; 5.233$ & $0.38 ; 0.36$ & $0.484 ; 0.401$ \\
\hline Mean value & 38.17 & 5.243 & 0.37 & 0.443 \\
\hline Standard deviation & 0.05 & 0.014 & 0.01 & 0.059 \\
\hline
\end{tabular}

Comparative analysis showed that the extract from aloe has a high content of $\mathrm{C}, \mathrm{H}$ and $\mathrm{S}$, while the extract from kalanchoe has a higher content of $\mathrm{N}$.

The cytotoxicity of plant extracts of kalanchoe and aloe on MM cells was assessed by staining the cells with trypan blue.

Table 2. Determination of the cytotoxicity of plant extracts of Aloe and Kalanchoe on MM cells. Values are given as mean \pm S.D. of three independent experiments.

\begin{tabular}{c|c|c|c|c} 
Experiment name & $\begin{array}{c}\text { Total number of } \\
\text { cells }\end{array}$ & $\begin{array}{c}\text { Amount living } \\
\text { cells }\end{array}$ & Amount dead cells & Cytotoxic index, \% \\
\hline $\begin{array}{c}\text { Before adding Aloe } \\
\text { to MM cells }\end{array}$ & 2016000 & 2016000 & 0,0 & 0,0 \\
\hline $\begin{array}{c}\text { After adding Aloe to } \\
\text { MM cells }\end{array}$ & 2112000 & 1056000 & 1056000 & 50 \\
\hline $\begin{array}{c}\text { Before adding } \\
\text { Kalanchoe to MM } \\
\text { cells }\end{array}$ & 2016000 & 2016000 & 0,0 & \\
\hline $\begin{array}{c}\text { After adding } \\
\text { Kalanchoe to MM } \\
\text { cells }\end{array}$ & 2508000 & 1188000 & 1020000 & 47,8 \\
\end{tabular}


Cell counting using trypan blue showed that all cells were initially alive (2 016000$)$ (Table 2). However, after incubation of cells with plant extract of aloe for 24 hours, the number of living cells was 1056000 , and the number of dead cells was 1056000. The cytotoxic index for aloe extract was $50 \%$ (Table 2).

After adding kalanchoe extract to MM cells, the number of living cells was 1188 000, and the number of dead cells was 1020 000. The cytotoxic index for kalanchoe extract was $47.8 \%$ (Table 2). This indicates that the plant extracts of aloe and kalanchoe exhibit cytotoxic properties.

We then investigated the effect of plant extracts of kalanchoe and aloe on the viability of $\mathrm{MM}$ cells. We evaluated the effect of plant extracts on MM cells' viability using a fluorescence method that measures the activity of mitochondrial NADH dehydrogenases [23]. The results showed that pre-incubation of MM cells with plant extracts of aloe and kalanchoe inhibited the activity of mitochondrial NADH dehydrogenases and thereby reduced the viability of MM tumor cells (Figure 3).

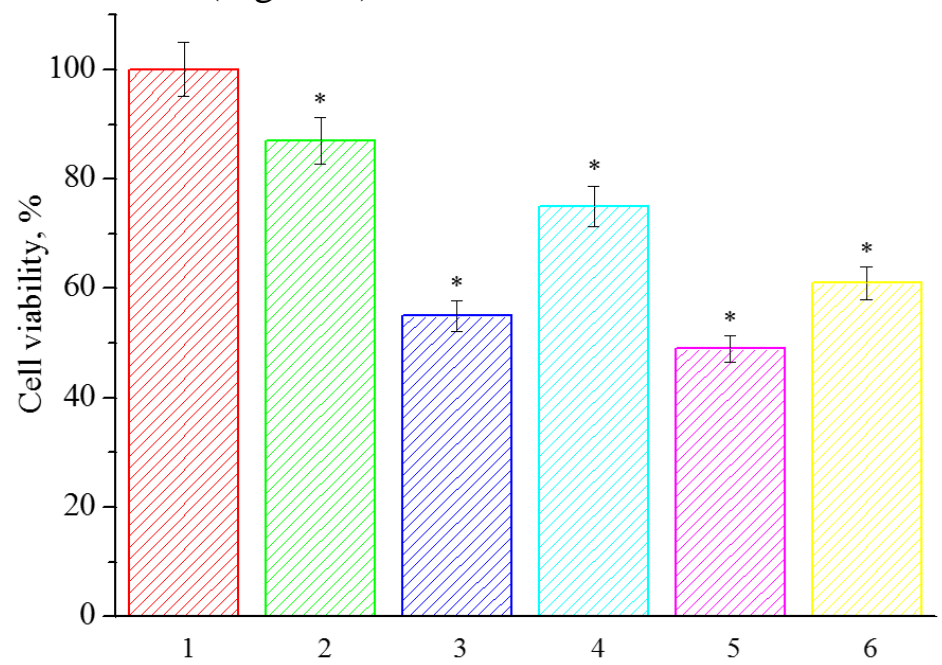

Figure 3. The effect of plant extracts Kalanchoe daigremontiana and Aloe arborescens on MM survival: 1-cells (control), 2-kalanchoe, 3-aloe, 4-Dox+kalanchoe, 5-Dox+aloe, 6-Dox. Here and in Figure 4-7 values are given as mean \pm S.D. of three independent experiments. ${ }^{*} \mathrm{P} \leq 0.05$ represents significant changes from untreated control.

As can be seen from Figure 3, the kalanchoe inhibited cell viability by $15 \%$. The combined use of kalanchoe with doxorubicin increased the effect; cancer cells' viability decreased by up to $25 \%$.

It should be noted that aloe extract exhibited a stronger effect since it inhibited MM cells' viability by $45 \%$ and in combination with doxorubicin by $50 \%$. By itself, doxorubicin inhibited cell viability by only $35 \%$. These results indicate that the combined use of plant extracts in conjunction with doxorubicin is more effective for possible use in cancer polychemotherapy.

Since we showed that plant extracts' action reduced MM cells' viability, we wanted to further understand the mechanism of action of extracts on the cell's metabolic pathways. And since it is known that cell survival depends on the level of reduced glutathione in the cell, we further studied the effect of plant extracts on the level of reduced glutathione in MM cells [30]. It was previously shown that the level of oxidative stress in the cell depends on the ratio of the reduced and oxidized forms of glutathione [30]. To understand whether plant extracts induce oxidative stress in MM cells, we investigated the effect of kalanchoe and aloe extracts on 
intracellular glutathione levels. The study results showed that MM cells' treatment with plant extracts led to a decrease in intracellular reduced glutathione.

It was shown that the intracellular glutathione level decreased by $25 \%$ under kalanchoe extract and $63 \%$ under the action of aloe (Figure 4).

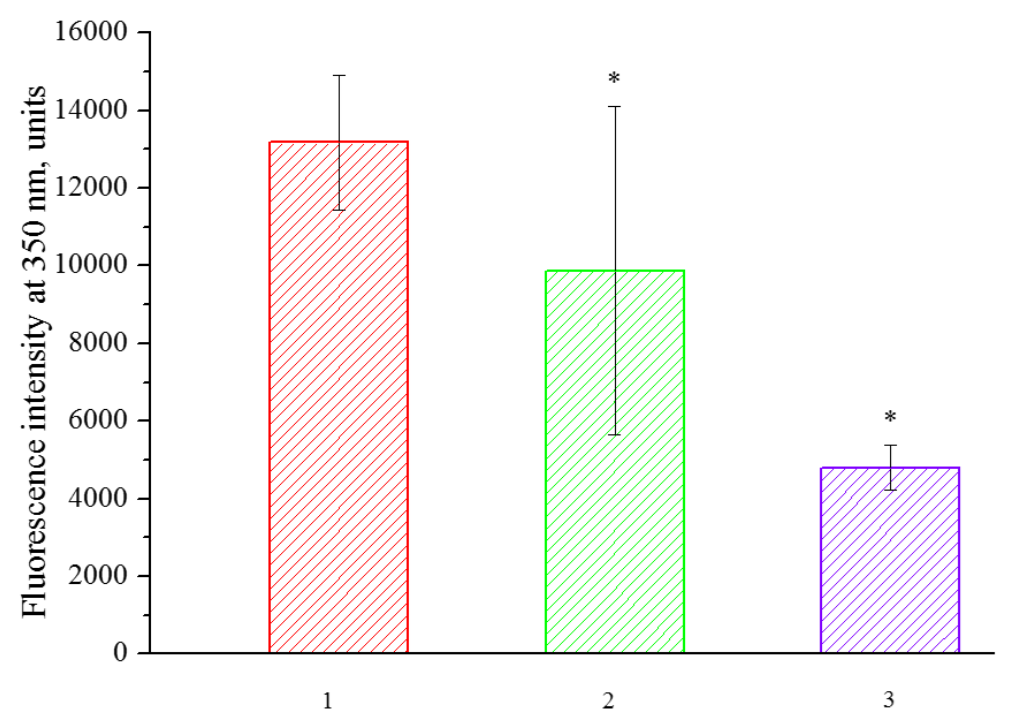

Figure 4. The effect of plant extracts Kalanchoe daigremontiana and Aloe arborescens on the level of reduced glutathione in MM cells: 1-cells (control), 2-cells+kalanchoe, 3-cells+aloe.

This indicates that the plant extracts induce oxidative stress in MM cells. It should be noted that aloe extract causes the most significant oxidative stress in cancer cells; its effect is 2.5 times higher than that of kalanchoe extract.

It is known from the literature that the mitochondrial membrane potential is an important indicator of the metabolic activity of cells; besides, it reflects the ability of mitochondria to generate reactive oxygen species [31]. A decrease in the membrane potential of mitochondria indicates the activation of the mitochondrial pathway of apoptosis. It is the cause of oxidative stress [32]. To understand why there is a decrease in cancer cells' viability, we further studied plant extracts' effect on the level of mitochondrial potential in MM cells.

As a result of our research, we found that plant extracts of kalanchoe and aloe decreased mitochondrial membrane potential. In particular, kalanchoe extract decreased by $19 \%$, and aloe extract by $53 \%$ (Figure 5).

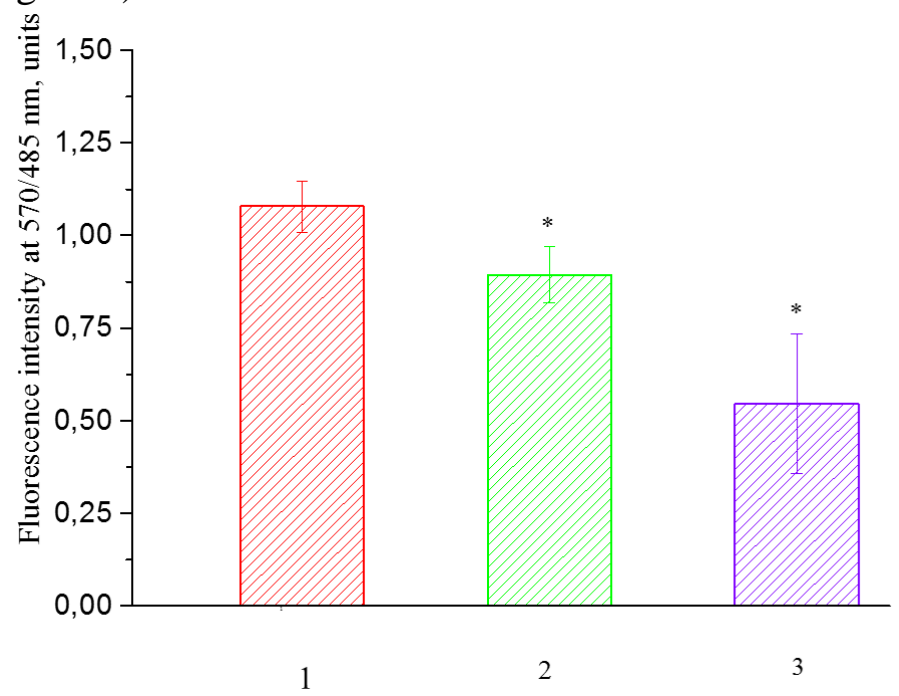

Figure 5. Influence of plant extracts Kalanchoe daigremontiana and Aloe arborescens on the mitochondrial membrane potential of MM: 1-cells (control), 2-cells+kalanchoe, 3-cells+aloe. 
It should be emphasized that aloe extract significantly reduced the level of membrane potential in MM cells compared to kalanchoe's action. The effect of aloe is 2.8 times that of the kalanchoe. This indicates that aloe is the most powerful oxidant than kalanchoe. These data are consistent with the data on plant extracts' effect on the viability and glutathione level in MM cells. Thus, the results obtained indicate that kalanchoe and aloe's plant extracts may induce oxidative stress in MM cells and thus cause their death.

To understand the mechanism of action of plant extracts on cancer cells, we further investigated the effect of kalanchoe and aloe extracts on the cell's energy profile, particularly the activity of ATPase and the amount of ATP. The study results showed that kalanchoe extract increased ATPase activity by $\sim 2$ times and aloe extract by 1.2 times (Figure 6). The data indicate that aloe extract does not affect the level of ATPase activity in the cell since the differences with control cells are not statistically significant.

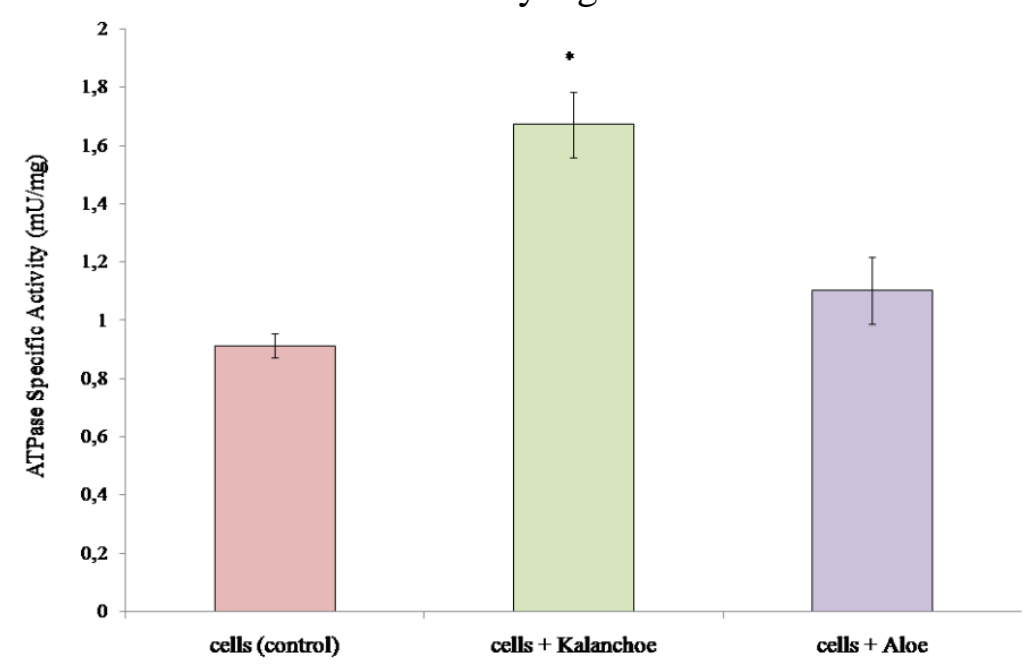

Figure 6. Influence of plant extracts Kalanchoe daigremontiana and Aloe arborescens on ATPase activity of MM cells.

Determination of the amount of synthesized ATP in the cells showed that Kalanchoe extract increased the ATP level by $\sim 2$ times and Aloe extract by $\sim 1.2$ times, which is consistent with the data on the effect of these extracts on ATPase activity (Figure 7).

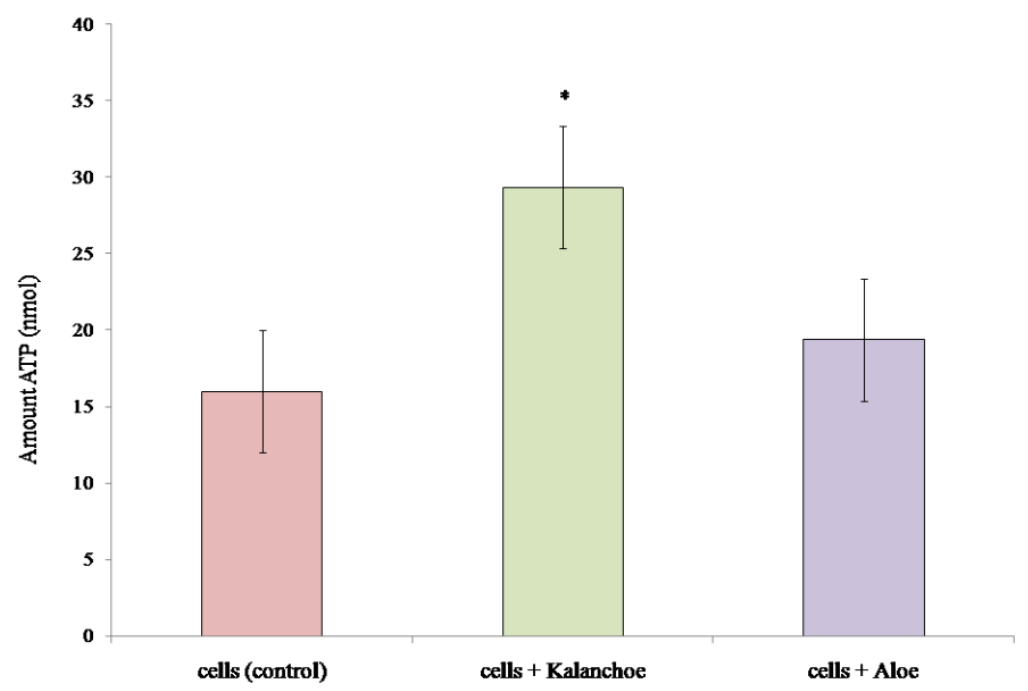

Figure 7. Influence of plant extracts Kalanchoe daigremontiana and Aloe arborescens on the total amount of ATP in MM cells.

Thus, the results obtained indicate that the plant extract of kalanchoe induced ATPase activity in cells, but the aloe extract did not affect the level of enzyme and amount of ATP. 


\subsection{Discussion.}

In this work, we obtained plant extracts from Kalanchoe daigremontiana leaves and aloe stems (Aloe arborescens) and studied their antitumor activity on human MM cells. Biologically active substances in the composition of kalanchoe and aloe extracts were analyzed by optical and NMR spectroscopy, organic elemental analysis. The spectroscopic studies of Kalanchoe daigremontiana extract showed alkaloids, bioflavonoids (rutin, quercetin), and anthocyanins flavonoids (flavanones, flavanonols, flavones), phenolic glycosides, triterpenoids, bryophylline. This extract's optical spectrum has absorption maxima characteristic of these compounds [33-35]. Earlier, bufanodienolides, bryophylline A, B, and $\mathrm{C}$ were identified in the Taiwanese Kalanchoe Bryophyllum pinnatum, and it was shown that they are cytotoxic compounds [35,36]. It was found that bryophyllin A, isolated from Bryophyllum pinnatum and Kalanchoe gracilis, has the strongest antitumor activity [34, 36]. Analysis of the spectra of aloe showed that it contains phenolic compounds, such as anthrone, anthraquinone, pyrone, chromone, aloenin, aloemodin, identified earlier $[15,16]$. The absorption spectra obtained by us and ${ }^{1} \mathrm{H}$ NMR spectroscopy data indicate the presence of similar compounds in the composition of aloe tree. Earlier, the antitumor activity from the leaves of Kalanchóe pinnáta was shown on cervical cancer cells using the MTT test [37]. Coarse extracts from Kalanchóe pinnáta leaves (at a concentration of $552 \mu \mathrm{g} / \mathrm{ml}$ ) inhibited the growth of HeLa cancer cells by $30 \%$ after 24 hours. Aloe-emodin, isolated from Aloe vera, showed antitumor activity on various human tumor cell lines, particularly breast cancer cells, melanoma, and ovarian cancer cells [38-40]. However, there are no data in the literature on the antitumor activity of plant extracts from Kalanchoe daigremontiana and Aloe arborescens on MM cells. Our study results showed that kalanchoe extract inhibited MM cells' viability by $13 \%$ after 24 hours (at a concentration of $17 \mathrm{mg} / \mathrm{ml}$ ), and aloe extract inhibited the viability of $\mathrm{MM}$ cells by $46 \%$ (at a concentration of $45 \mathrm{mg} / \mathrm{ml}$ ). It was found that plant extracts of kalanchoe and aloe inhibited the activity of mitochondrial NADH dehydrogenases, which are responsible for the synthesis of ATP in cells [41]. Therefore, in this work, we have shown for the first time that plant extracts from Kalanchoe daigremontiana and Aloe arborescens have cytotoxic properties since the survival of tumor cells significantly decreases under their action. It should be noted that aloe extract is a more effective cytostatic compared to kalanchoe, since it inhibits the growth of MM cells 3.5 times more strongly. Aloe extract was even more effective compared to doxorubicin, a well-known anti-cancer drug that only reduced MM cell viability by $39 \%$. The combined use of aloe extracts with doxorubicin enhanced the antitumor effect. The results showed that treatment of aloe cells and doxorubicin decreased MM cells' survival by $50 \%$, but MM cells' treatment simultaneously with kalanchoe and doxorubicin decreased cell viability by $25 \%$. These results showed an additive, synergistic effect and suggest that herbal extracts of aloe and kalanchoe can be used in cancer polychemotherapy.

Besides, our results showed that the addition of plant extracts of kalanchoe and aloe to MM cells leads to a decrease in mitochondrial dehydrogenases' functional activity, which is usually accompanied by impaired cellular energy production, damage to mitochondria, and the development of mitochondrial dysfunction [23,41]. Therefore, the next stage of our study was to study the effect of plant extracts of aloe and kalanchoe on mitochondrial membrane potential. For the first time, we have shown that treatment of MM cells with extracts from Kalanchoe daigremontiana and Aloe arborescens led to a decrease in mitochondrial membrane potential by 19 and $53 \%$, respectively. At the same time, the action of aloe extract was 2.8 times more 
effective than kalanchoe. It is known that a decrease in the level of the mitochondrial membrane potential indicates the activation of the mitochondrial apoptosis pathway [42]. Therefore, we can assume that, like most cytotoxic phytocompounds, plant extracts from Kalanchoe daigremontiana and Aloe arborescens induced apoptotic cell death through the loss of mitochondrial membrane potential.

It is now known that elevated glutathione levels in tumor cells protect cancer cells in the bone marrow, breast, colon, larynx, and lungs during cancer development, creating resistance to several chemotherapeutic drugs $[43,44]$. Therefore, compounds that reduce the level of glutathione in cancer cells may be useful in chemotherapy for cancer [45]. Our results demonstrated for the first time that plant extracts from Kalanchoe daigremontiana and Aloe arborescens reduced glutathione levels in MM cells by 25 and 63\%, respectively. It is known that a disturbance in the balance of oxidized/reduced glutathione in the cell leads to oxidative stress and the accumulation of reactive oxygen species [43-45]. It is likely that a decrease in the level of reduced glutathione in MM cells under the action of extracts from Kalanchoe daigremontiana and Aloe arborescens leads to oxidative stress and thereby causes the death of cancer cells.

\section{Conclusions}

Thus, the experiments' results showed that the plant extracts Kalanchoe daigremontiana and Aloe arborescens affect tumor cells' metabolism, have antitumor activity, and are potential antitumor drugs for the treatment of multiple myeloma. However, further research is needed to understand their mechanism of action better. Future scientific work on the purification of plant extracts from the leaves of Kalanchoe daigremontiana and Aloe arborescens and in vivo studies help uncover the full therapeutic potential of these extracts as effective anti-cancer drugs.

\section{Funding}

This research was funded by the Ministry of Science and Higher Education of the Russian Federation and performed under the state task, state registration \# AAAA-A19-1190718900156.

\section{Acknowledgments}

The authors would like to express their gratitude to the Analytical Center for Collective Use of the IPCP RAS and REC MGOU "Medical Chemistry" at the IPCP RAS (Chernogolovka, Moscow area, Russia) for supporting this study. We express our gratitude to Chernyak A.V. ( $\mathrm{PhD}$, Head of the NMR spectroscopy Department, IPCP RAS) for his help in the analysis of NMR spectra; and to Nemirova L.S. (PhD, Head of Department of Botany, Moscow Regional State University) for advice on medicinal plants.

\section{Conflicts of Interest}

The authors declare no conflict of interest. The funders had no role in the study's design, in the collection, analyses, or interpretation of data, in the writing of the manuscript, or in the decision to publish the results. 


\section{References}

1. Kouitcheu Mabeku, L.B.; Eyoum Bille, B.; Tchouangueu, T.F.; Nguepi, E.; Leundji, H. Treatment of Helicobacter pylori infected mice with Bryophyllum pinnatum, a medicinal plant with antioxidant and antimicrobial properties, reduces bacterial load. Pharm. Biol. 2017, 55, 603-610, https://doi.org/10.1080/13880209.2016.1266668.

2. Valgimigli, M. The remarkable story of a wonder drug, which now comes to an end in the primary prevention setting: say bye-bye to aspirin! Eur. Heart J. 2019, 40, 618-620, https://doi:10.1093/eurheartj/ehy872

3. Donoghue, M.J. Adaptation meets dispersal: legumes in the land of succulents. New Phytol. 2019, 222, 16671669, https://doi.org/10.1111/nph.15834.

4. Lie, A.K.; Greene, J.A. From Ariadne's Thread to the Labyrinth Itself-Nosology and the Infrastructure of Modern Medicine. The New England journal of medicine 2020, 382, 1273-1277, https://doi.org/10.1056/NEJMms1913140.

5. Vázquez-González, Y.; Ragazzo-Sánchez, J.A.; Calderón-Santoyo, M. Characterization and antifungal activity of jackfruit (Artocarpus heterophyllus Lam.) leaf extract obtained using conventional and emerging technologies. Food Chem. 2020, 330, 127211, https://doi.org/10.1016/j.foodchem.2020.127211.

6. Santos, S.; Haslinger, C.; Mennet, M.; von Mandach, U.; Hamburger, M.; Simões-Wüst, A.P. Bryophyllum pinnatum enhances the inhibitory effect of atosiban and nifedipine on human myometrial contractility: an in vitro study. BMC Complement. Altern. Med. 2019, 19, 292, https://doi.org/10.1186/s12906-019-2711-5.

7. Morais Fernandes, J.; Ortiz, S.; Padilha M. Tavares, R.; Mandova, T.; Rodrigues D. Araújo, E.; L. Andrade, A.W.; Michel, S.; Grougnet, R.; Zucolotto, S.M. Bryophyllum pinnatum markers: CPC isolation, simultaneous quantification by a validated UPLC-DAD method and biological evaluations. J. Pharm. Biomed. Anal. 2021, 193, 113682, https://doi.org/10.1016/j.jpba.2020.113682.

8. Stefanowicz-Hajduk, J.; Hering, A.; Gucwa, M.; Hałasa, R.; Soluch, A.; Kowalczyk, M.; Stochmal, A.; Ochocka, R. Biological activities of leaf extracts from selected Kalanchoe species and their relationship with bufadienolides content. Pharm. Biol. 2020, 58, 732-740, https://doi.org/10.1080/13880209.2020.1795208.

9. Bao, W.-R.; Li, Z.-P.; Zhang, Q.-W.; Li, L.-F.; Liu, H.-B.; Ma, D.-L.; Leung, C.-H.; Lu, A.-P.; Bian, Z.-X.; Han, Q.-B. Astragalus Polysaccharide RAP Selectively Attenuates Paclitaxel-Induced Cytotoxicity Toward RAW 264.7 Cells by Reversing Cell Cycle Arrest and Apoptosis. Front. Pharmacol. 2019, 9, 1580, https://doi.org/10.3389/fphar.2018.01580.

10. Seca, A.M.L.; Pinto, D.C.G.A. Plant Secondary Metabolites as Anticancer Agents: Successes in Clinical Trials and Therapeutic Application. Int. J. Mol. Sci. 2018, 19, 263, https://doi.org/10.3390/ijms19010263.

11. Gulumian, M.; Yahaya, E.S.; Steenkamp, V. African Herbal Remedies with Antioxidant Activity: A Potential Resource Base for Wound Treatment. Evid. Based Complement. Alternat. Med. 2018, 2018, 4089541, 4089541, https://doi.org/10.1155/2018/4089541.

12. Ullah, A.; Munir, S.; Badshah, S.L.; Khan, N.; Ghani, L.; Poulson, B.G.; Emwas, A.-H.; Jaremko, M. Important Flavonoids and Their Role as a Therapeutic Agent. Molecules 2020, 25, 5243, https://doi.org/10.3390/molecules25225243.

13. Marasek-Ciolakowska, A.; Saniewski, M.; Dziurka, M.; Kowalska, U.; Góraj-Koniarska, J.; Ueda, J.; Miyamoto, K. Formation of the Secondary Abscission Zone Induced by the Interaction of Methyl Jasmonate and Auxin in Bryophyllum calycinum: Relevance to Auxin Status and Histology. Int. J. Mol. Sci. 2020, 21, 2784, https://doi.org/10.3390/ijms21082784.

14. Richwagen, N.; Lyles, J.T.; Dale, B.L.F.; Quave, C.L. Antibacterial Activity of Kalanchoe mortagei and K. fedtschenkoi Against ESKAPE Pathogens. Front. Pharmacol. 2019, 10, 67, https://doi.org/10.3389/fphar.2019.00067.

15. Ren, J.-J.; Wang, J.; Lee, K.-K.; Deng, H.; Xue, H.; Zhang, N.; Zhao, J.-C.; Cao, T.; Cui, C.-L.; Zhang, X.$\mathrm{H}$. The complete chloroplast genome of Aloe vera from China as a Chinese herb. Mitochondrial DNA Part B 2020, 5, 1092-1093, https://doi.org/10.1080/23802359.2020.1726229.

16. Liu, C.; Cui, Y.; Pi, F.; Cheng, Y.; Guo, Y.; Qian, H. Extraction, Purification, Structural Characteristics, Biological Activities and Pharmacological Applications of Acemannan, a Polysaccharide from Aloe vera: A Review. Molecules 2019, 24, 1554, https://doi.org/10.3390/molecules24081554.

17. Chihara, T.; Shimpo, K.; Beppu, H.; Tomatsu, A.; Kaneko, T.; Tanaka, M.; Yamada, M.; Abe, F.; Sonoda, S. Reduction of intestinal polyp formation in min mice fed a high-fat diet with Aloe vera gel extract. Asian Pac. J. Cancer Prev. 2013, 14, 4435-4440, https://doi.org/10.7314/apjcp.2013.14.7.4435. 
18. Chen, R.; Zhang, J.; Hu, Y.; Wang, S.; Chen, M.; Wang, Y. Potential Antineoplastic Effects of Aloe-emodin: A Comprehensive Review. The American Journal of Chinese Medicine 2014, 42, 275-288, https://doi.org/10.1142/S0192415X14500189.

19. Harlev, E.; Nevo, E.; Lansky, E.P.; Ofir, R.; Bishayee, A. Anticancer potential of aloes: antioxidant, antiproliferative, and immunostimulatory attributes. Planta Med. 2012, 78, 843-852, https://doi.org/10.1055/s-0031-1298453.

20. Huang, P.-H.; Huang, C.-Y.; Chen, M.-C.; Lee, Y.-T.; Yue, C.-H.; Wang, H.-Y.; Lin, H. Emodin and AloeEmodin Suppress Breast Cancer Cell Proliferation through $\mathrm{ER}<\mathrm{b}><\mathrm{i}>\mathrm{\alpha}</ \mathrm{i}></ \mathrm{b}>$ Inhibition. Evid. Based Complement. Alternat. Med. 2013, 2013, 376123, https://doi.org/10.1155/2013/376123.

21. Suboj, P.; Babykutty, S.; Valiyaparambil Gopi, D.R.; Nair, R.S.; Srinivas, P.; Gopala, S. Aloe emodin inhibits colon cancer cell migration/angiogenesis by downregulating MMP-2/9, RhoB and VEGF via reduced DNA binding activity of NF-кB. Eur. J. Pharm. Sci. 2012, 45, 581-591, https://doi.org/10.1016/j.ejps.2011.12.012.

22. Javaid, R.; Qazi, U.Y. Catalytic Oxidation Process for the Degradation of Synthetic Dyes: An Overview. Int. J. Env. Res. Public Health 2019, 16, 2066, https://doi.org/10.3390/ijerph16112066.

23. Schreer, A.; Tinson, C.; Sherry, J.P.; Schirmer, K. Application of Alamar blue/5-carboxyfluorescein diacetate acetoxymethyl ester as a noninvasive cell viability assay in primary hepatocytes from rainbow trout. Anal. Biochem. 2005, 344, 76-85, https://doi.org/10.1016/j.ab.2005.06.009.

24. Owen, J.B.; Butterfield, D.A. Measurement of Oxidized/Reduced Glutathione Ratio. Methods Mol Biol. 2010, 648, 269-77, https://doi: 10.1007/978-1-60761-756-3_18.

25. Sur, S.; Nakanishi, H.; Flaveny, C.; Ippolito, J.E.; McHowat, J.; Ford, D.A.; Ray, R.B. Inhibition of the key metabolic pathways, glycolysis and lipogenesis, of oral cancer by bitter melon extract. Cell Communication and Signaling 2019, 17, 131, https://doi.org/10.1186/s12964-019-0447-y.

26. Bradford, M.M. A rapid and sensitive method for the quantitation of microgram quantities of protein utilizing the principle of protein-dye binding. Anal. Biochem. 1976, 72, 248-254, https://doi.org/10.1006/abio.1976.9999.

27. Gregorczyk, K.P.; Wyżewski, Z.; Szczepanowska, J.; Toka, F.N.; Mielcarska, M.B.; Bossowska-Nowicka, M.; Gieryńska, M.; Boratyńska-Jasińska, A.; Struzik, J.; Niemiałtowski, M.G.; Szulc-Dąbrowska, L. Ectromelia Virus Affects Mitochondrial Network Morphology, Distribution, and Physiology in Murine Fibroblasts and Macrophage Cell Line. Viruses 2018, 10, 266, https://doi.org/10.3390/v10050266.

28. Afzal, M.; Kazmi, I.; Anwar, F. Antineoplastic potential of Bryophyllum pinnatum Lam. on chemically induced hepatocarcinogenesis in rats. Pharmacognosy Res. 2013, 5, 247-253, https://doi.org/10.4103/09748490.118811 .

29. El Abdellaoui, S.; Destandau, E.; Toribio, A.; Elfakir, C.; Lafosse, M.; Renimel, I.; André, P.; Cancellieri, P.; Landemarre, L. Bioactive molecules in Kalanchoe pinnata leaves: extraction, purification, and identification. Anal. Bioanal. Chem. 2010, 398, 1329-1338, https://doi.org/10.1007/s00216-010-4047-3.

30. Moine, L.; Rivoira, M.; de Barboza, G.D.; Pérez, A.; de Talamoni, N.T. Glutathione depleting drugs, antioxidants and intestinal calcium absorption. World J. Gastroenterol. 2018, 24, 4979-4988, https://doi.org/10.3748/wjg.v24.i44.4979.

31. Hou, X.-S.; Wang, H.-S.; Mugaka, B.P.; Yang, G.-J.; Ding, Y. Mitochondria: promising organelle targets for cancer diagnosis and treatment. Biomaterials Science 2018, 6, 2786-2797, https://doi.org/10.1039/c8bm00673c.

32. Jiban, B.; Ritesh, K.; Gundappa, S.; Kartikeya, T.; Vikash, K.D. Apoptosis: Mediator Molecules, Interplay with Other Cell Death Processes and Therapeutic Potentials. Curr. Pharm. Biotechnol. 2018, 19, 644-663, https://doi.org/10.2174/1389201019666180821093239.

33. Damien, B.G.; Baxerres, C.; Apetoh, E.; Le Hesran, J.-Y. Between traditional remedies and pharmaceutical drugs: prevention and treatment of "Palu" in households in Benin, West Africa. BMC Public Health 2020, 20, 1425, https://doi.org/10.1186/s12889-020-09479-7.

34. García-Pérez, P.; Lozano-Milo, E.; Landin, M.; Gallego, P.P. From Ethnomedicine to Plant Biotechnology and Machine Learning: The Valorization of the Medicinal Plant Bryophyllum sp. Pharmaceuticals (Basel) 2020, 13, 444, https://doi.org/10.3390/ph13120444.

35. Santos, S.; Haslinger, C.; Klaic, K.; Faleschini, M.T.; Mennet, M.; Potterat, O.; von Mandach, U.; Hamburger, M.; Simões-Wüst, A.P. A bufadienolide-enriched fraction of Bryophyllum pinnatum inhibits human myometrial contractility in vitro. Planta Med. 2019, 85, 385-393, https://doi.org/10.1055/a-0810-7704. 
36. Bogucka-Kocka, A.; Zidorn, C.; Kasprzycka, M.; Szymczak, G.; Szewczyk, K. Phenolic acid content, antioxidant and cytotoxic activities of four Kalanchoë species. Saudi J. Biol. Sci. 2018, 25, 622-630, https://doi.org/10.1016/j.sjbs.2016.01.037.

37. Mahata, S.; Maru, S.; Shukla, S.; Pandey, A.; Mugesh, G.; Das, B.C.; Bharti, A.C. Anticancer property of Bryophyllum pinnata (Lam.) Oken. leaf on human cervical cancer cells. BMC Complement. Altern. Med. 2012, 12, 15, https://doi.org/10.1186/1472-6882-12-15.

38. Tseng, H.-S.; Wang, Y.-F.; Tzeng, Y.-M.; Chen, D.-R.; Liao, Y.-F.; Chiu, H.-Y.; Hsieh, W.-T. Aloe-Emodin Enhances Tamoxifen Cytotoxicity by Suppressing Ras/ERK and PI3K/mTOR in Breast Cancer Cells. The American Journal of Chinese Medicine 2017, 45, 337-350, https://doi.org/10.1142/S0192415X17500215.

39. Tabolacci, C.; Cordella, M.; Turcano, L.; Rossi, S.; Lentini, A.; Mariotti, S.; Nisini, R.; Sette, G.; Eramo, A.; Piredda, L.; De Maria, R.; Facchiano, F.; Beninati, S. Aloe-emodin exerts a potent anticancer and immunomodulatory activity on BRAF-mutated human melanoma cells. Eur. J. Pharmacol. 2015, 762, 283292, https://doi.org/10.1016/j.ejphar.2015.05.057.

40. Zhang, L.-q.; Lv, R.-w.; Qu, X.-d.; Chen, X.-j.; Lu, H.-s.; Wang, Y. Aloesin Suppresses Cell Growth and Metastasis in Ovarian Cancer SKOV3 Cells through the Inhibition of the MAPK Signaling Pathway. Anal. Cell. Pathol. 2017, 2017, 8158254, https://doi.org/10.1155/2017/8158254.

41. Barclay, C.J.; Loiselle, D.S. An Equivocal Final Link - Quantitative Determination of the Thermodynamic Efficiency of ATP Hydrolysis - Sullies the Chain of Electric, Ionic, Mechanical and Metabolic Steps Underlying Cardiac Contraction. Front. Physiol. 2020, 11, 183, https://doi.org/10.3389/fphys.2020.00183.

42. Abdelaal, M.R.; Soror, S.H.; Elnagar, M.R.; Haffez, H. Revealing the Potential Application of EC-Synthetic Retinoid Analogues in Anticancer Therapy. Molecules. 2021, 26, 506, https://doi: 10.3390/molecules26020506.

43. Xiao, Z.; La Fontaine, S.; Bush, A.I.; Wedd, A.G. Molecular Mechanisms of Glutaredoxin Enzymes: Versatile Hubs for Thiol-Disulfide Exchange between Protein Thiols and Glutathione. J. Mol. Biol. 2019, 431, 158-177, https://doi.org/10.1016/j.jmb.2018.12.006.

44. Kanda, H.; Kumagai, Y. Redox Signaling and Reactive Sulfur Species to Regulate Electrophilic Stress. Yakugaku Zasshi 2020, 140, 1119-1128, https://doi.org/10.1248/yakushi.20-00096.

45. Hatem, E.; El Banna, N.; Huang, M.-E. Multifaceted Roles of Glutathione and Glutathione-Based Systems in Carcinogenesis and Anticancer Drug Resistance. Antioxidants \& Redox Signaling 2017, 27, 1217-1234, https://doi.org/10.1089/ars.2017.7134. 